\title{
Design and Application Mode of Micro Class Design for PWM Speed Regulating of DC Motor
}

\author{
Xiang $\mathrm{Li}^{1, \text { a }}$, Muzi Zhuge ${ }^{1, \mathrm{~b}}$ and Nan Zhao ${ }^{1, \mathrm{c}, \text { * }}$ \\ ${ }^{1}$ Tianjin University of Technology and Education, China, 300222 \\ acklx90@163.com, ${ }^{\mathrm{b}}$ muzi_40105@163.com, ${ }^{\mathrm{c}} \mathrm{dxczh007@163.com}$
}

Keywords: Experimental Teaching, Micro Class, PWM Speed Regulating of DC Motor, Autonomic Learning

\begin{abstract}
This paper designs a comprehensive experiment for two important knowledge points, timer and interrupt, in course microcontroller practice technology. To improve teaching effect, we develop related micro class scripts and micro class video, planning to build a micro class digital integrated platform architecture, and puts forward the three stage application model for experiment teaching. The practice proves that the teaching PWM speed regulating of DC motor lesson in this paper has the advantages of improving the efficiency of teaching, improving the quality of teaching and cultivating students' autonomous learning habits.
\end{abstract}

\section{Introduction}

Microcontroller practice technology is very important required course in electronic specialty. Timer and interrupt are difficult points of electrical knowledge[1]. In the lab class, students just type the code, observe phenomena of experimental box, so they could not absorb these source code of knowledge points. In theory teaching, student still use the method of rote learning to get the knowledge points. We want to find a way to change the rote learning, developing absorptivity of knowledge[2].

\section{Experiment Teaching Background}

Experiment teaching reform of mcrocontroller practice technology has been tried a variety of approaches. Especially, the integrated teaching has achieved good results. Because of the low cost of experiment hardware, students can learn knowledge by operating hardware. But in limited time, we have to arrange basic experiments based syllabus. But teacher cannot solve all problems, so we decide on using micro class to increase the way of access to knowledge.

Teaching and learning has evolved from narrow classroom teaching to multi-dimensional in modern education philosophy. The development of the internet also promoted the innovation of education. Now, education informationization is no longer the single way to show slideshow, but network of education through the internet. Teachers realize the diversity of classroom patterns through mooc and flipped classroom.

From the perspective of teachers, introducing other advanced teaching methods can greatly reduce the work intensity, so that teachers have the energy to enrich the classroom teaching activities. Introducing advanced technologies can indirectly improve student-faculty ratios, students are not entangled with some conceptual problems. teachers can summarize students learning results after feedback timely adjusting contents and schedule.

By introducing modern teaching methods, students can feel the experiment more intuitive. The theoretical knowledge, experimental procedures and experimental phenomena are finally merged into one to realize the effective link between knowledge and knowledge.

\section{Mode Framework}

The micro class mode is mainly composed of micro-courseware, micro-teaching case, 
micro-problem, etc., which constitutes a "teaching resource package" with distinct theme and prominent emphasis. Micro class mode using the three dimensional animation, video, and the rich teaching resources, such as pictures, sounds in the limited time to achieve more resources of fine clip arrangement, through a variety of perception model and terminal receiving mode, support the students use the fragment time for autonomous learning, greatly expanded the teaching scope of space and time, improve the efficiency and the effect of classroom teaching. Therefore, the introduction of micro class mode has been a beneficial attempt and discussion to solve the adverse factors in the experimental teaching of the above traditional tool parameters.

To make a good micro lesson, we must make a good plan of the script, including selecting the knowledge points appropriately, preparing the course resources, designing the teaching process, choosing video display mode and recording mode, etc.

\section{Experimentation Contents}

Around the timer and interrupt experiment contents on the overall teaching syllabus content analysis, the core content is divided into the timer works about experiment analysis, interrupt priority level analysis, the PWM duty cycle adjustable waveform core principles, signal detection. In order to facilitate the students to master the timer and interrupt the two main points of knowledge, the course will supplement and review the classroom teaching content based on the timer basic experiment and the interrupted basic experiment. The detailed planning contents are shown in table 1.

Table 1 Analysis of the content of experiment

\begin{tabular}{|c|c|c|}
\hline Course Title & \multicolumn{2}{|c|}{ Timer \& Interrupt } \\
\hline Teaching Objectives & \multicolumn{2}{|c|}{$\begin{array}{l}\text { Understand and learn to PWM adjustable duty for wave } \\
\text { of practical application. } \\
\text { Familiar with multimeter. }\end{array}$} \\
\hline Keywords & MCU8051; Work manner; & Interrupt; PWM \\
\hline Chapter & Section & Knowledge Point \\
\hline \multirow{4}{*}{$\begin{array}{c}\text { PWM Speed Regulating of DC } \\
\text { Motor }\end{array}$} & $\begin{array}{c}\text { Timer } \\
\text { Interrupt } \\
\text { Motor operation effect 1 }\end{array}$ & $\begin{array}{l}\text { Work manner } \\
\text { Process of interrupt } \\
\text { Voltage of dc motor at variable } \\
\text { speed }\end{array}$ \\
\hline & Motor operation effect 2 & $\begin{array}{l}\text { How to control motor speed by } \\
\text { program }\end{array}$ \\
\hline & Program description 1 & $\begin{array}{l}\text { The relation between the } \\
\text { change of program variable } \\
\text { and motor speed }\end{array}$ \\
\hline & Program description 2 & $\begin{array}{l}\text { How to generate PWM wave } \\
\text { through timer and interrupt } \\
\text { program }\end{array}$ \\
\hline
\end{tabular}

You need to do a good script design before recording micro class video. The logical and clear script is the guarantee for the smooth recording of micro class, and also the guarantee of the practicability and usability of video. PWM speed regulating of DC motor experiment is shown in table 2. Video will design the experiment into eight lens images to ensure the logic of video production, and also facilitate the implementation of video based on the course group and improve the efficiency of micro class development. 
Table 2 Microscript design reference

\begin{tabular}{|c|c|c|c|c|}
\hline $\begin{array}{l}\text { Micro } \\
\text { course } \\
\text { number }\end{array}$ & 001 & Title & PWM Speed Regulating of DC Mot & \\
\hline Number & Split screen & Voice-over & Content & Tine \\
\hline 1 & Experiment name & $\begin{array}{l}\text { PWM } \\
\begin{array}{l}\text { Regulating of } \\
\text { Motor }\end{array}\end{array}$ & $\begin{array}{l}\text { PWM Speed Regulating of DC } \\
\text { Motor }\end{array}$ & $1 \mathrm{~s}$ \\
\hline 2 & Objectives and conditions & $\begin{array}{l}\text { Master experimental } \\
\text { content and required } \\
\text { hardware }\end{array}$ & $\begin{array}{l}\text { Experimental purpose and } \\
\text { experimental conditions }\end{array}$ & $15 \mathrm{~s}$ \\
\hline 3 & $\begin{array}{l}\text { Composition of knowledge } \\
\text { points }\end{array}$ & $\begin{array}{l}\text { Introduce } r \text { the } \\
\text { theoretical knowledge } \\
\text { points }\end{array}$ & Basic theoretical knowledge & $15 \mathrm{~s}$ \\
\hline 4 & $\begin{array}{l}\text { The electric signal display of } \\
\text { the dc motor at different speeds } \\
\text { ( Picture and video } \\
\text { demonstration) }\end{array}$ & $\begin{array}{l}\text { The relationship } \\
\text { between hardware and } \\
\text { program }\end{array}$ & $\begin{array}{l}\text { Check the voltage of the key } \\
\text { when pressing the button. } \\
\text { Check the voltage at both ends of } \\
\text { the motor when pressed. }\end{array}$ & $180 \mathrm{~s}$ \\
\hline 5 & $\begin{array}{l}\text { PWM waveform analysis } \\
\text { ( Picture and video } \\
\text { demonstration) }\end{array}$ & $\begin{array}{l}\text { The relationship } \\
\text { between PWM } \\
\text { waveform and program } \\
\text { and motor speed }\end{array}$ & $\begin{array}{l}\text { Change the parameters of PWM } \\
\text { wave in the program, observe the } \\
\text { motor speed and check the } \\
\text { voltage on both ends of the motor }\end{array}$ & $180 \mathrm{~s}$ \\
\hline 6 & Qualitative analysis & & $\begin{array}{l}\text { The function of timer and } \\
\text { interrupt in PWM } \\
\begin{array}{l}\text { regulating of Deed } \\
\text { experiment. }\end{array}\end{array}$ & $180 \mathrm{~s}$ \\
\hline
\end{tabular}

With the preparation of micro script design and material, we can start the production of video. Mainstream production methods include using micro class tool software + PPT, use the equipment directly to record the teaching video recording, using an electronic whiteboard software to record, use the tablet + "graffiti" use tools to record, record the screen recording software, etc..In view of the characteristics of this course and the types of material resources, we select "video screen software +PPT+ video" to make micro-courses. Through the preparation of the PPT of the experiment course, the motor speed regulation video recording, and the processing of the material resources such as video recording of the electric signal, the recording software Camtasia Studio was used to make the video recording.

Platform architecture is shown in figure 1. System development of platform adopts B/S architecture, which consists of database server, Web server, TCP/IP network. Database Server configures SQL Server 2000 SP4 and Windows Server 2003.Through the development of the platform, system provide micro-course design and production services to teachers and micro-courses online learning, experiment and testing services to students.

\begin{tabular}{|c|cccc|}
\hline $\begin{array}{c}\text { Resource } \\
\text { layer }\end{array}$ & $\begin{array}{c}\text { Online } \\
\text { learning }\end{array}$ & $\begin{array}{c}\text { Experiment } \\
\text { simulation }\end{array}$ & $\begin{array}{c}\text { Online to } \\
\text { answer }\end{array}$ & Access \\
\hline $\begin{array}{c}\text { Application } \\
\text { layer }\end{array}$ & $\begin{array}{c}\text { Micro class } \\
\text { design module }\end{array}$ & $\begin{array}{c}\text { Micro class } \\
\text { production } \\
\text { module }\end{array}$ & $\begin{array}{c}\text { Micro class } \\
\text { release module }\end{array}$ & $\begin{array}{c}\text { Assessment } \\
\text { feedbackmodule }\end{array}$ \\
\hline $\begin{array}{c}\text { Resource } \\
\text { layer }\end{array}$ & PPT library & $\begin{array}{c}\text { Animation } \\
\text { video library }\end{array}$ & $\begin{array}{c}\text { Micro class } \\
\text { library }\end{array}$ & $\begin{array}{c}\text { Script outline } \\
\text { window library }\end{array}$ \\
\hline
\end{tabular}

Fig.1 Platform architecture

After the completion of video, it is only half of the work to complete the micro-course teaching. How to make full use of the micro-course video is the maximization of its mobile teaching advantage. In general, video can be used as a teaching method for innovative courses, such as 
flipped classroom and mooc. It can also be used as part of a hybrid curriculum. In this paper, we use the three basic concepts of quality control, namely, "advance to the event" and propose the application mode of "pre-class preview -- classroom guidance -- after-school reference". Specifically by the service platform or offline methods, according to the experiment courses provide students with the corresponding micro class schedule video could help students in the experimental class preview experiment content. In the experiment class, teachers give priority to in order to play micro lesson video way to introduce the experiment content, so they can cost a large number of experiment for students' operation innovation. After the experiment, students can refer to video to complete the experiment report, combining video with video to deepen the understanding of abstract principles and theories in the engineering training.

\section{Conclusion}

Adopting micro teaching model, students can learn the own arrangement in the experimental class has time to watch the micro video class, experimental purpose, task, and have fully understand the basic concept, as well as combining the theory of teaching materials for relevant concepts of review. So in experiment class, teacher could focus on interpretation of the difficulty, using 15 to 20 minutes to complete the experiment teaching link, which can be used for more than $75 \%$ of the class hours students operation, effective practice time increased by $30 \%$ or so. In the future, we will conduct in-depth study on the micro-course system and the construction of the platform, establishing a complete curriculum design and production resources and application mode.

\section{Acknowledgement}

In this paper, the research was sponsored by Foundation of Tianjin University of Technology and Education (Project No. XJKC0314A7) and Planning Comprehensive Investment Plan for the 13th Five-year Plan of Tianjin University of Technology and Education (Project No. SSW16326).

\section{References}

[1] Nan Wang, Yingshu Chen. Research on Teaching-Reform Method for Single-Chip Microcomputer Course Based on Innovative Applied Talent Training Mode [J]. EDUCATION TEACHING FORUM, 20178 93-95.

[2] Li MO, Hongping YU, Xin HE. Reform and Practice of the Teaching System Forsingle Chip Microcomputer [J]. Education and Teaching Research 201630 (6) 105-110. 